\title{
Non Structural Element its Behaviour during an Earthquake
}

\author{
*Mr. Santosh Kumar ${ }^{1}$, Mr. Nand Kumar Sharma ${ }^{2}$ \\ ${ }^{1}$ - Assistant Professor, SSGI, Junwani (BHILAI) INDIA \\ ${ }^{2}-$ Student $4^{\text {th }}$ semester M.Tech. (Structure), SSGI, Junwani (BHILAI) INDIA \\ Corresponding author: Mr. Santosh Kumar
}

\begin{abstract}
Non structural elements in a building are those members which come in to the path of earthquake force affected by it but do not take part in the dissipation of energy produced during an earthquake. Failure of these members during an earthquake causes not only economic losses but human life too. The building will remain safe after an earthquake but may become unserviceable for the purpose for which it has been constructed. For the earthquake resistant design of building study of behavior of these members is necessary. It has been found that seismic design of structure is given much attention but very little attention has been given to protecting non structural member of the buildings ${ }^{1}$. This article has been prepared after studying codes and articles published in various journals. The main objective of this article is to make design people aware of the importance of non structural element in the earthquake resistant design of buildings.

Keywords: Non structural element, Earthquake, Behavior,
\end{abstract}

Date of Submission: 12 -07-2017

Date of acceptance: 20-07-2017

\section{INTRODUCTION}

Non structural elements are those members in buildings which are non earthquake resistant. They do not take part in load resisting system of earthquake forces.

They are supposed to be stable during earthquake due to their own weight. But in actual case this does not happen. It is found that earthquakes of moderate to severe intensity causes only moderate to heavy damage. While earthquakes of only moderate intensity causes severe destruction to non structural elements ${ }^{2}$ it is found in last many earthquakes that major hospitals have been shut down due to the failure of life saving equipments.

In Bhuj earthquake collapse of several water tanks located over roof tops caused injury to human life and water supply has been disrupted. Lack of attention in the design of non structural system and the increased complexities have resulted in majority of losses in recent earthquakes. Today development of performance based earthquake resistant design requires harmonization of performance level between the structural and non structural elements become essential ${ }^{3}$.

This article has been prepared after reviewing various journals and publications in this subject. This article is to explain different types of non structural elements and behavior of these members during an earthquake.

Knowledge of behavior makes us possible to design proper connections.

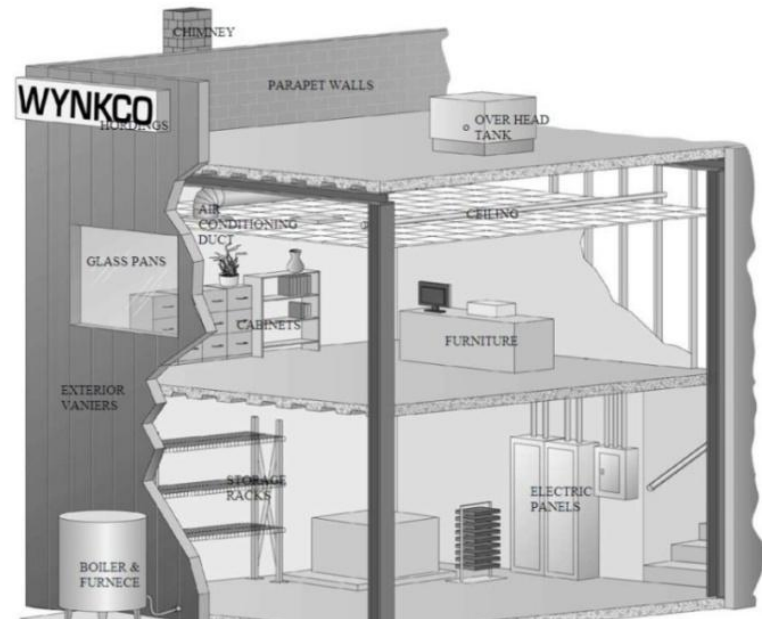

Figure 1- A three dimensional figures showing structural and non structural member in a building

\section{NON STRUCTURAL ELEMENT}

Non structural elements are members within and outside buildings. They are not earthquake resisting part of buildings. They are affected by the earthquake forces and cause damage to themselves and people nearby during an earthquake. They are contents within the buildings, Architectural elements, mechanical and electrical components of the building. The contents within the building are simple storage shelves to complicated plating facilities, bottled gas storage to sophisticated high tech facilities. Architectural item consists of false ceiling, decorative lights, exterior facade partitions etc. Mechanical and electrical components 
are Transformers, switch gears, boiler, chillers and other plants, piping, air conditioning ducts. A more specific list of non structural element is categorized by IBC. The IBC also provides design coefficients for each category that is applied to the component to establish the design seismic forces.
Similarly when a member with large length attached at more than one place to the structural member is shaken by earthquake force member will slide, twist or shake or combination of this movement will occur. For example pipe of water main running along the height of the building, pipe is shaken differentially between the successive support points

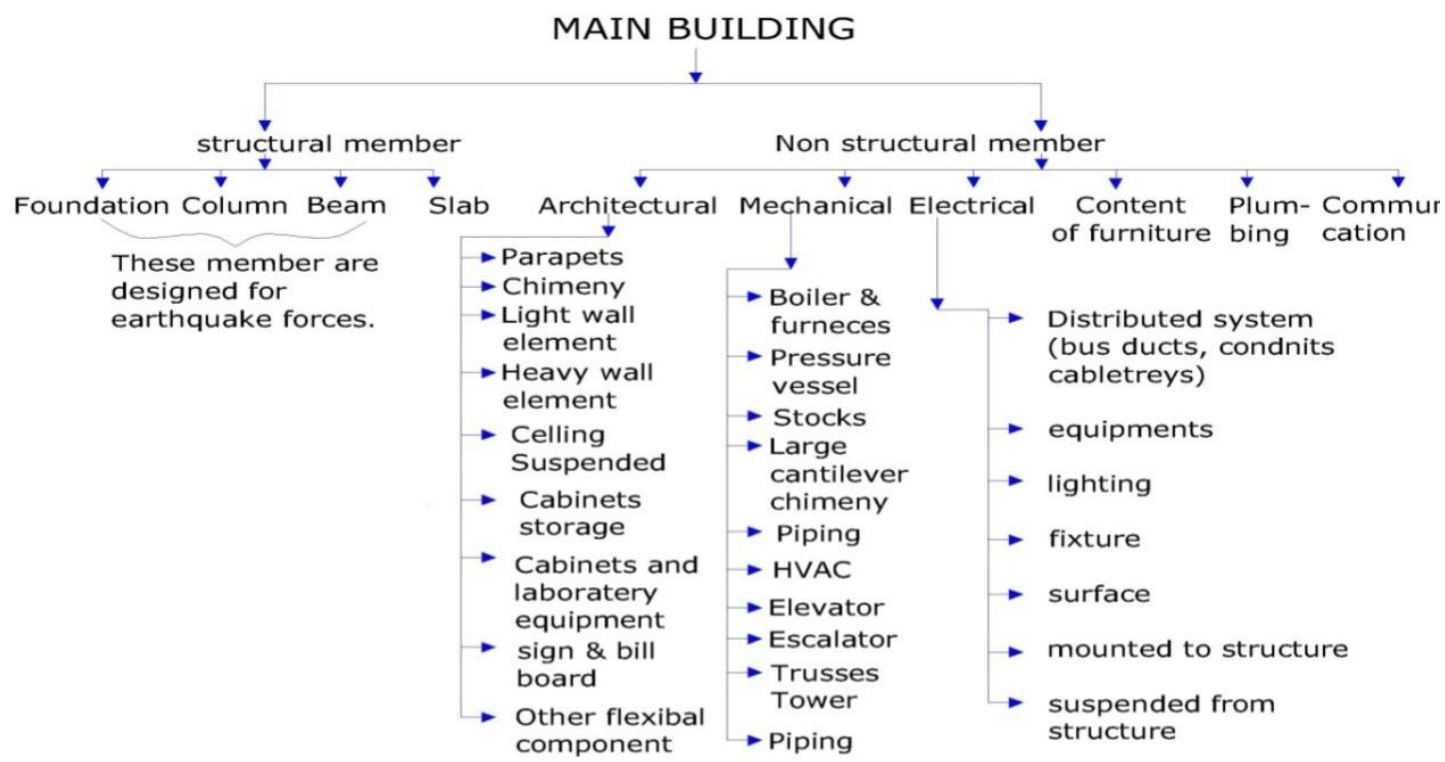

Figure 2 Atypical broad category of non structural elements in three dimensional forms is shown in figure 1 , also in the chart form in figure2

\section{BEHAVIOR OF NON STRUCTURAL ELEMENT DURING AN EARTHQUAKE}

We can imagine a person seating in a moving vehicle when the vehicle is suddenly stopped the person seated in side without seat belt will slip away from the seat and may injure him. Similarly during an earthquake, waves are generated, unsecured objects are placed over the structure will slide, topple or collide with each other and may injure to the people at the same time fallen object may prevent the rescue operation by blocking the passage and exit. During an Earthquake the acceleration will be different at Different floor levels of buildings ${ }^{4}$. The non structural element placed at different floor level will be accelerated. This acceleration will be different than the main structure over which it is placed. It will experience acceleration more than 12 times that of the main structure. The identical members placed at different floor levels will experience different amount of shaking. A body with large mass and large height than the base surface is shaken slightly it will remain stable. When it is or shaken moderately it will slide severely and rock or even topple. at the floor levels. The relative movement $\mathrm{D}$ is in the horizontal direction and transverse to the pipe, irrespective of direction of shaking.

Thus as per the behavior of on structural member during an earth quake it can be broadly classified as

(i) Force Sensitive elements (ii) Displacement sensitive element (iii) Both force sensitive and displacement sensitive element. ${ }^{4}$

3.1 Force sensitive Elements - These elements are stiff and heavy. They slide, rock and topple during an earthquake. The force experienced during an earth quake by these elements increases with the increase in the floor level of building. For example heavy storage racks overturning may cause economical and human loss.

3.2 Displacement sensitive elements- These elements move or swing into translation and rotation during an earthquake. They give impact to nearby non structural element and also pulled apart. The non structural element connected to two adjacent buildings like sewage pipe line joints open up leading to loss of function, Glass facade breakage can harm people.mes without bracing or shear walls for resisting the lateral loads 


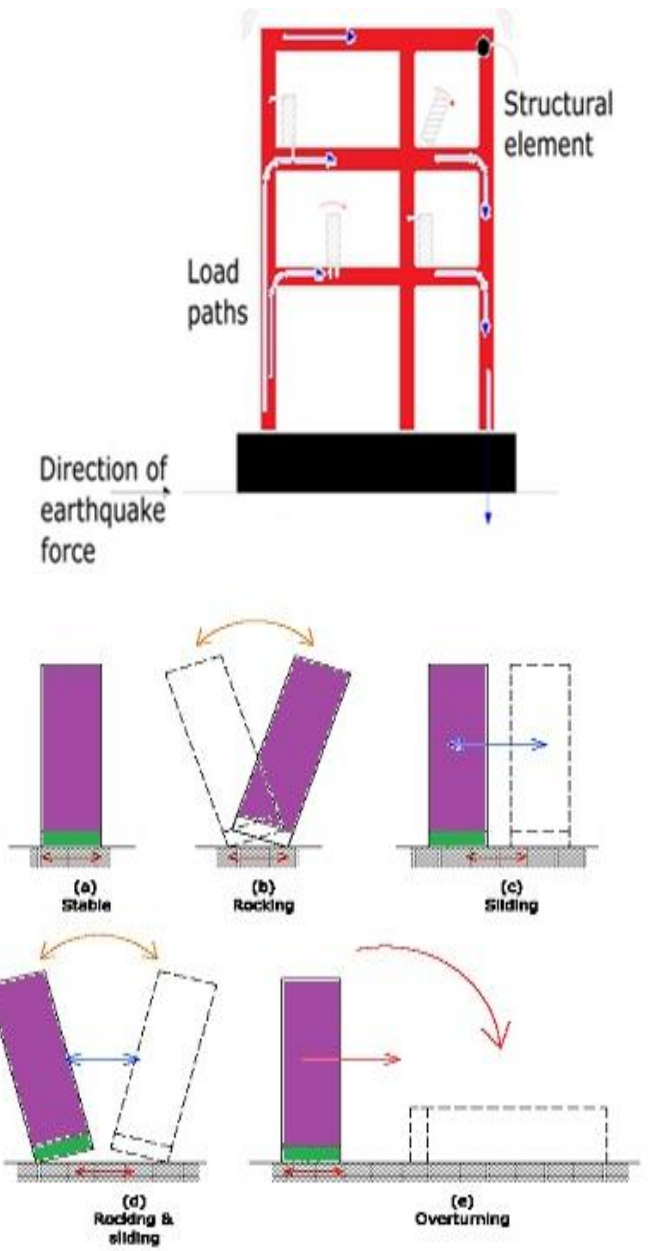

Figure 3- showing behaviour of unsecured nonstructural element during an earthquake.

Table 2.1: Categorization Of commonly used NSEs in a buildings as per their behaviour during an earthquake

Force Sensitive, Displacement Sensitive \& Both Sensitive

\begin{tabular}{|l|l|l|}
\hline \multicolumn{1}{|c|}{ Force } & \multicolumn{1}{c|}{ Displacement } & \multicolumn{1}{c|}{ Both } \\
\hline $\begin{array}{l}\text { 1. Storage } \\
\text { shelves }\end{array}$ & $\begin{array}{l}\text { 1. Water supply } \\
\text { pipelines }\end{array}$ & $\begin{array}{l}\text { 1. Doors } \\
\text { and }\end{array}$ \\
material stacks & $\begin{array}{l}\text { 2. Electricity } \\
\text { cables \& wires } \\
\text { 3. Gas pipelines }\end{array}$ & $\begin{array}{l}\text { windows } \\
\text { 2. Large- } \\
\text { panel glass } \\
\text { panes with }\end{array}$ \\
\hline $\begin{array}{l}\text { 1. Sewage } \\
\text { Refrigerators }\end{array}$ & pipelines & frames (as \\
2. Washing & 5. & window or \\
machines & Telecommunicati & infill \\
3. Gas & on wires & walling \\
cylinders & 6. Rainwater drain & material) \\
4. TVs & pipes & 3. Other \\
5. Diesel & 7. Elevators & Partitions \\
generators & 8. Fire hydrant & 4. False \\
\hline
\end{tabular}

\begin{tabular}{|c|c|c|}
\hline $\begin{array}{l}\text { 6. Water } \\
\text { pumps(small) } \\
\text { 7. Window } \\
\text { ACs } \\
\text { 8. Wall } \\
\text { mounted ACs }\end{array}$ & $\begin{array}{l}\text { systems } \\
\text { 9. Air- } \\
\text { conditioning ducts }\end{array}$ & $\begin{array}{l}\text { ceilings } \\
5 . \\
\text { Suspended } \\
\text { flooring } \\
\text { system }\end{array}$ \\
\hline $\begin{array}{l}\text { 1. Flat bottom } \\
\text { containers and } \\
\text { vessels } \\
\text { 2. Structurally } \\
\text { Supported } \\
\text { Vessels }\end{array}$ & & \\
\hline $\begin{array}{l}\text { 2. Boilers and } \\
\text { Furnaces } \\
\text { 2. General } \\
\text { manufacturing } \\
\text { and process } \\
\text { machinery } \\
\text { 3. HVAC } \\
\text { Equipment }\end{array}$ & & \\
\hline
\end{tabular}

\section{CONCLUSION}

From the above discussion following conclusion have been made

(i) Non structural elements are non earthquake force resisting members of buildings. They are Architectural members, storage facilities, electrical and mechanical equipments within and out side the buildings.

(ii) Development of modern construction has increased the non structural part in buildings than the structural part.

(iii) Economical and human loss due to the failure of non structural members during an earthquake has increased.

(iv) After the development of performance based earthquake resistant buildings it becomes necessary to have harmonious performance of non structural member with the structural member.

(v) The same member placed at different level of floors of a building experience different amount of forces for the same earthquake. There are a large number of non structural members in a building. They have different and complex behaviour at elastic and non elastic range of earthquake forces. So it becomes difficult to judge the amount of force coming on it during an earthquake. A specific guide line has to be prepared. 
(vi) During massive earthquake which may be more than IV on MMI scale it is necessary to have life saving buildings like hospitals , communication centres, water supply and electric supply will remain functional. It is only possible if the non structural members are properly connected to structural member and connection will remain intact.

(vii) There is inadequate provision for non structural elements in Indian Seismic Code IS1893:2002 and they are said to be none existent ${ }^{7}$.

(viii) USA has prepared guide line in FEMA E 74/ december2012 "Reducing risk of Non Structural Earthquake damage- A practical guide". Similarly New Zealand has prepared NZA4219 (2009) "Seismic performance of Engineering System in Buildings".

(ix) A Guide line prepared by GSDMA Government of Gujarat in form of Guide line for the protection of Non Structural Elements in Building is useful for the design engineers

\section{REFERENCES}

[1]. James L. Stratta, Manual of seismic design, Building contents Non structural Items, P.184 Pearson Educational International.

[2]. Anand Swarup Arya, seismic safety of non structural element and content in hospital buildings ,P4, GOI-UNDP Disaster risk Management Programme.

[3]. www.eucentre.it/non-structural-element /1/16/2017

[4]. Suresh L. Dhanani, Sumant B.Patel, Snehal V. Mehta, Seismic Response of Non Structural Elements, IJIET Vol. @ Issue 2 April2013

[5]. CVR Murty, Rupen Goswami, A.R. Vijayanarayanan, R. Pradeep Kumar, Vipul V. Mehta Introduction to Earthquake Protection of Non Structural Elements in Building, P 24, GSDMA Government of Gujrat

[6]. NEHRP, FEMA74/December 11 Reducing the Risk of Non Structural Earthquake Damage- a Practical guide

[7]. Goutam Mondal \& Sudhir K. Jain, Design of Non-structural elements for Buildings : A review of Codal Provisions, Indian Concrete Journal, Aug 2005, P 22

International Journal of Engineering Research and Applications (IJERA) is UGC approved Journal with Sl. No. 4525, Journal no. 47088. Indexed in Cross Ref, Index Copernicus (ICV 80.82), NASA, Ads, Researcher Id Thomson Reuters, DOAJ.

Mr. Santosh Kumar. "Non Structural Element its Behaviour during an Earthquake." International Journal of Engineering Research and Applications (IJERA) 7.7 (2017): 26-29. 